\title{
The Effect of a Computer Program Based on Analysis, Design, Development, Implementation and Evaluation (ADDIE) in Improving Ninth Graders' Listening and Reading Comprehension Skills in English in Jordan
}

\author{
Talal Alodwan ${ }^{1} \&$ Mosaab Almosa $^{1}$ \\ ${ }^{1}$ College of Educational Sciences, The World Islamic Sciences and Education University, Amman, Jordan \\ Correspondence: Talal Alodwan, College of Arts and Human Sciences, The World Islamic Sciences and \\ Education University, Amman, Jordan. Tel: 962-795-333-711. E-mail: talaladwan@yahoo.com
}

Received: January 20, 2018 Accepted: March 12, 2018 Online Published: March 14, 2018

doi: 10.5539/elt.v11n4p43 URL: http://doi.org/10.5539/elt.v11n4p43

\begin{abstract}
The study aimed to assess the effectiveness of a computer program based on Analysis, Design, Development, Implementation and Evaluation (ADDIE) Model on the achievement of Ninth Graders' listening and Reading Comprehension Skills in English. The study sample comprised 70 ninth graders during the second semester of the academic year 2016/2017. The selected students were distributed into two groups: an experimental group and a control one. A computer program based on Analysis, Design, Development, Implementation and Evaluation (ADDIE) was prepared, and a 40-item listening test in addition to a 40-item reading comprehension test were designed according to modules outcomes which were presented in (Teachers' Book Action Pack 9). Validity and reliability were ensured for both tests. The results showed a statistically significance difference at $(\alpha=0.05)$ between the mean scores of the control compared to the experimental group on both tests (listening achievement test and reading comprehension achievement test) due to the independent variable implementing a computerized program based on ADDIE Model in favor of the experimental group.
\end{abstract}

Keywords: ADDIE, listening skill and reading comprehension, EFL instruction in Jordan

\section{Introduction}

\subsection{Introduction of the Problem}

There are four skills in learning a language: listening, speaking, reading, and writing. Listening and reading are called receptive or passive skills, and speaking and writing are productive or active skills. Whichever way we wish to sub-classify the language skills, one cannot deny the fact that all function together in an integrated manner. In actual practice, however, the language teacher still deals with each skill separately, identifying the errors committed by the students and suggesting possible remedies (Singhal \& Vohra, 2011). Teachers need to understand that the problems their students face in reading, speaking, and writing may be related to inadequate listening skills which are the foundation of all the other language skills (Petty, 2004).

It is possible to help students to improve their listening and reading comprehension skills by using a computer program which is designed on Instructional Design (ID), particularly on analysis, design, development, implementation and evaluation (ADDIE). According to Marrison (2002), web-based activities can be updated easily to support students at different proficiency levels, and foreign-language teachers have found ways to integrate technology into their lesson planning and instruction. The use of web-enabled learners gives access to a range of online language learning resources.

So, in this study, the researcher investigated whether using a computer program based ADDIE model may help in improving listening and reading comprehension for ninth graders in English.

\subsection{Statement of the Problem}

One of the major problems for students of English as a Foreign Language (EFL) is their lack of listening and reading comprehension skills. This may be as a result of the minimal exposure to English in general and to listening and reading comprehension skills activities in particular. Despite the fact that Jordanian English school 
books require active listening and reading comprehension skills, the schools seem to neglect these pivotal skills, so the issue needs to be addressed (Al-Karian, 2011).

The problem investigated in this study comes from the obvious weakness in the basic stages of gaining English Language skills, particularly listening and reading comprehension skills (Al-Zo'ubi, 2001; Jarrah, 2008; Al Jamal, 2009; Al-Karian, 2011).

\subsection{Study Questions}

The study addresses 'what is the effect of a computer program based on the ADDIE model in improving Jordanian Ninth Graders' listening and reading comprehension skills in English Language through answering the following two questions :

1) Are there any statistically significant differences $(\alpha=0.05)$ between the mean scores of the control group and the experimental group on the listening comprehension test due to the teaching strategy (a computer program based on ADDIE Model?

2) Are there any statistically significant differences $(\alpha=0.05)$ between the mean scores of the control group and the experimental group on the reading comprehension test due to the teaching strategy (a computer program based on ADDIE Model?

\subsection{Significance of the Study}

The importance of the study is confirmed by the Ministry of Education's continuous attention to improving students' knowledge of the English language, to achieve the Ministry's long-term goals, especially communicating with others.

It is hoped that authors and developers of English curricula for the basic stage will benefit from the finding of study; which illustrates the importance of listening and reading comprehension skills in English language learning. This study also encourages supervisors and teachers to use a variety of teaching methods departing from the traditional teaching methods and improving the teaching-learning process, if these methods prove to be effective.

It is hoped that the students themselves will benefit from the study; through improving their listening and reading comprehension skills and becoming proficient in English language. Finally, the study will contribute to the relevant literature in TEFL.

\subsection{Definitions of Terms}

1) The computer program: the program was designed by the researcher for modules five and six (listening and reading comprehension activities) of the ninth-grade English Curriculum.

2) Instructional Design: reading in depth the material to be designed, then analyzing, and organizing it in a manner that makes it easier for students to understand the designed material and remember; it testing and evaluation the designed material.

3) Reading comprehension: the student's ability to understand written text correctly and express this understanding orally or in written form. Reading comprehension can be measured through tests.

4) Ninth Grade Students: male students aged 14-15 years old and enrolled in a public, private or International relief agency school.

5) Action Pack 9: English language teaching book assigned by the Jordanian Ministry of Education to the ninth Grade students.

\section{Method}

\subsection{Study Approach}

The researcher assigned the participants randomly into two groups: a control group and an experimental group. Each group had thirty-five male students. The study dealt with one independent variable which is a computer program based on ADDIE Model. The two dependent variables are students' scores on the listening comprehension test and students' scores on the reading comprehension test.

\subsection{Study Participants}

The participants were chosen purposefully. They were two ninth grade sections (35 male students in each). The school was chosen purposefully on the condition that it had to have a computer laboratory equipped with not less than twenty computer sets. One section (A) was assigned as an experimental group, and the other section (B) was assigned as a control group. The experimental group was taught using a computer program based on ADDIE 
Model and the control group was taught traditionally.

\subsection{Instruments of the Study}

The researcher used three research instruments: a computer-based program based on ADDIE Model, a listening comprehension test and a reading comprehension test

\subsubsection{ADDIE Model}

Aldoobie (2015: 68) remarked that: ADDIE model is one of the most common models used in the instructional design field a guide to producing an effective design. The elements made by following the ADDIE model can be used in any environment as online or face-to-face. In addition, this systematic process is represented in the acronym ADDIE, which stands for Analysis, Design, Development, Implementation, and Evaluation.These phases provide dynamic and flexible guidelines which are used for effective and efficient instruction.

Analysis Phase

Analysis stage is the most important phase in this process.. In order to carry out the analysis phase we have to analyze four things; we have to analyze the learners, develop an instructional analysis, create instructional goals, and analysis's learning objectives. That means you have to be clear about your goals and where you want your learners to be (Aldoobie, 2015).

Design Phase

Design phase is really about applying the instruction, in design phase the instructional designer evolves and focuses on designing assessment for (his/her) topic, select a form of the course, and create their own instructional strategy (Aldoobie, 2015).

Development Phase

In this phase, the instructional designers integrate the technology with the educational setting and process. Moreover, the instructional designer starts to develop and create a good quality factual sample for the instruction design, the materials of the course, and run through of the conduction of the course (Aldoobie, 2015).

\section{Implementation Phase}

This phase is about putting our plan into action. In order to go through this phase, we have to consider three major steps, which are training the instructors, preparing the learners, and organizing the learning environment. With these three steps we can display our course in very active and authentic ways to achieve the implementation phase (Aldoobie, 2015).

Evaluation Phase

It is very important to evaluate each step in order to make sure that our goals are achieved by using the instructional design and materials to meet the learner needs. (Aldoobie, 2015).

\subsubsection{The Listening Comprehension Test}

The test consisted of forty items and was designed according to the learning outcomes of Modules 5 and 6 which were found in the Teachers' Book (Action Pack 9). The researcher built a test which consisted of six main types of questions: completion, Wh-questions, Yes/No, matching, multiple choice and short answer questions.

\subsubsection{The Reading Comprehension Test}

The test consisted of forty items and designed according to outcomes of Modules 5 and 6 which were found in Teachers' Book Action (Pack 9). The researcher built a test which consisted of six main types of questions: true or false, Wh-question, matching, referential pronouns, multiple choice and sentence ordering.

\subsection{Validity of Listening Skill Test and Reading Comprehension Test}

To ensure the content validity of the Listening Skill Test and Reading Comprehension Test, a jury of five university English instructors, two supervisors from the Ministry of Education and three English school teachers were asked to give their remarks about the instruments' validity. They suggested certain changes related to types of the questions, time of the test, weight of questions and variation of questions. Their suggestions were taken in account in modifying the instruments before they were applied.

\subsection{Reliability of Listening Skill Test and Reading Comprehension Test}

The researcher constructed a pre-post listening achievement testanda pre-post reading comprehension achievement test and administrated them to a pilot sample of 20 tenth grade students. The students tested and retested after fifteen days. By using Pearson Correlation Formula, the reliability coefficient stability was 
computed. It was 0.78 for listening achievement test and 0.77 for reading comprehension achievement test.

\subsection{The Instructional Program}

The researcher designed a computer-based program whose content was taken from the listening materials and the reading comprehension texts in Student's Book (Action Pack 9). These modules were designed based on ADDIE Model by using a computer. The questions and answers were accessed through the computer program to facilitate the listening and reading comprehension processes for the students. The design and development of the computer program were made with the help of a computer engineer.

\subsection{Building the Program}

The five phases of the ADDIE Model are:

\subsubsection{Analysis}

The Analysis Phase was conducted to determine the following (Manichander, 2016):

1. Students' levels in listening and reading comprehension skills in English.

2. The content of the teaching material.

3. Target outcomes of the program, and the instructional aims that the program concentrates on.

4. Various options available with respect to learning environment, and the most conducive learning environment.

5. Limiting factors to the program aim.

\subsubsection{Design}

During the design stage, the researcher connected with the designer who was a computer engineer through face to face interviews or through different social media. The researcher gave his notes on each part of the program and the designer edited:

1). Different types of media to be used. Audio, Video and Graphics are major examples. Audio scripts and reading text with pictures were utilized. The researcher prepared the teaching learning material.

2). Level and types of activity to be generated during the study depended on the nature of the task that the students were asked to do. Whether it is going to be collaborative, interactive or on a per participant basis

3). Knowledge and skill developed after each task. Teacher played the role of facilitator and organizer. After each task there was an exercise related to listening and reading comprehension skills students had to do.

4). The feedback mechanism the researcher used to determine if the participants are able to understand the lessons. Before practicing the computer program on the experimental group, the researcher practiced it on a pilot sample.

5). Given the various student preferences and learning styles. The design depended on mastery learning. Mastery learning maintains that students must achieve a level of mastery in prerequisite knowledge before moving forward to learn the following information. If students do not achieve mastery on the task, they are given additional support in learning and reviewing the information. This cycle continues until the learner accomplishes mastery, and they may then move on to the next stage.

In listening exercises a student can repeat the Audio scripts depending on his ability. In reading comprehension exercises, there were pictures which helped some students to get more explanations.

6). Pinpoint the main ideas of the project .To improve ninth grade students' listening and reading comprehension skills.

\subsubsection{Development}

The Development stage started with the production and the testing of the program methodology. The designers made use of the data collected from the two preceding stages; to create a program that will relay what needs to be taught to the students. This phase included three tasks, namely drafting, production and evaluation. Development thus involved creating and testing of learning outcomes. It aimed to address the following questions (Manichander, 2016):

Is the time frame being followed in relation to what has been accomplished in terms of material? Are you creating materials as per-schedule?

Through practicing the computer program on the pilot sample, the researcher found that the lesson time was very suitable to the computerized material. The researcher arranged the teaching material in a schedule as mentioned 
in the analysis stage.

\subsubsection{Implementation.}

This stage gained much feedback both from instructional designer and students alike. When teachers and learners actively contribute during the implementation process, instant modifications could be made to the project, thus making the program more effective and successful (Manichander, 2016).

The following are examples of what could be determined:

1). The emotional feedback given to the researcher by students during initial demonstration of the study. Are they genuinely interested, eager, critical or resistant?

2). How to deal with any possible errors during testing.

3). Did the researcher prepare a back-up tool in the event of initial failure of the program?

4). When the student group gets the material can they work independently, or is constant guidance required?

\subsubsection{Evaluation}

The main goal of the evaluation stage is to determine if the goals have been met, and to establish what will be required moving forward in order to further the efficiency and success rate of the project. The evaluation phase can be divided into two parts: Formative and Summative. The initial evaluation actually happens during the development stage. The Formative phase happens while students and Instructional Designers are conducting the study, while the Summative portion occurs at the end of the program (Manichander, 2016).

Evaluation is an essential step of the whole ADDIE method as it aims to determine the followings:

1). The categories that will be established to evaluate the project effectiveness.

2). The way that the researcher implemented in data collection, as well as the timing at which it will be effectively made.

3). The method by which reliability and content validity can be observed.

4). The method by which the researcher knows if instructions are clear. How is the clarity assessed?

5). Who gets to receive final output regarding the project?

\subsection{Validity of the Program}

After being designed by the help of a computer engineer, the program was judged by a jury of two university professors, and tow computer teachers from the Ministry of Education. The jury suggested certain changes related to the time, structure, and the presented material. These changes were made by the researcher with computer's engineer helping. Then, the program was given back to the jury. They all accepted the new version of the program and did not suggest any further changes or modifications.

\subsection{Procedures of the Study}

The researcher followed the following procedures to conduct this study:

1) Reviewing some of the related literature to establish a theoretical background.

2) Preparing the instruments of the study, and then establishing their validity and reliability.

3) Obtaining permission to conduct the study on the sample.

4) Analyzing the textbook modules to select the listening exercises and reading comprehension passages and exercises which were taught in the second semester of 2016/2017.

5) Designing and validating instructional program.

6) Identifying the participants of the study, and assigning the teachers to both groups (experimental and control).

7) Conducted a pre-test on the participants of the study and compute its results.

8) Training the teacher of the experimental group to teach the material.

9) Implementing the computer program on the experimental group.

10) Conducting a post-test on the participants of the study and computing its results.

11) Analyzing the results and writing the dissertation. 


\subsection{Design of the Study}

The non-equivalent groups design was used in this study. The pre-post test also was used. There were two groups: an experimental group and a control group. An experimental group was taught by using a computer program and a control group was taught traditionally. The two groups were tested by using pre-post test.

\begin{tabular}{ccc} 
Experimental Group O1 & $\mathrm{X}$ & $\mathrm{O} 2$ \\
\hline Control Group & $\mathrm{O} 1$ & $\mathrm{O} 2$
\end{tabular}

\section{Statistical Analysis}

1). To answer the first question, means, standard deviations and estimated marginal means of the achievement listening test were computed according to group variable and preceded by one way ANCOVA.

2). To answer the second question, means, standard deviations and estimated marginal means of the achievement reading comprehension test were computed according to group variable and preceded by one way ANCOVA.

\section{The Results of the Study}

\subsection{Results Related to the First Question}

The first question addressed whether there are any statistically significant differences $(\alpha=0.05)$ between the mean score of the control group and the experimental group on the listening comprehension test due to the teaching method (a computer program based on ADDIE model. To answer this question, Analysis of Covariance (ANCOVA) was used (Table 1).

Table 1. One way ANOCVA results of the listening comprehension test

\begin{tabular}{llllll}
\hline Source & Sum of Squares & Df & Mean Square & F & Sig. \\
\hline Pre-test (covariate) & 1161.434 & 1 & 1161.434 & 226.741 & .000 \\
Group & 451.260 & 1 & 451.260 & 88.097 & .000 \\
Error & 343.194 & 67 & 5.122 & & \\
Corrected Total & 2025.786 & 69 & & & \\
\hline
\end{tabular}

Table 1 shows that there are statistically significant differences $(\alpha=0.05)$ in the post test due to Independent Variable which is computerized method based on ADDIE Model in favor of Experimental group.

\subsection{Results Related to the Second Question}

The second question addressed whether there are any statistically significant differences $(\alpha=0.05)$ between the mean score of the control group and the experimental group on the reading comprehension test due to the teaching method (a computer program based on ADDIE model. To answer this question, Analysis of Covariance (ANCOVA) was used (Table 2).

Table 2. One way ANOCVA results of the achievement reading comprehension test

\begin{tabular}{llllll}
\hline Source & Sum of Squares & Df & Mean Square & F & Sig. \\
\hline Pre-test (covariate) & 1964.312 & 1 & 1964.312 & 271.389 & .000 \\
Group & 984.105 & 1 & 984.105 & 135.964 & .000 \\
Error & 484.945 & 67 & 7.238 & & \\
Corrected Total & 4139.771 & 69 & & & \\
\hline
\end{tabular}

Table 2 showed that there are statistically significant differences $(\alpha=0.05)$ in the post test due to independent variable which is computerized method based on ADDIE Model in favor of Experimental group. 


\section{Discussions of the Findings and Recommendations}

\subsection{Discussion of the Result of the First Question}

The findings of the present study show that there are statically significant differences between the two mean scores of the post response of the overall students' achievement on the listening comprehension test. This is due to the difference in the teaching method: the computerized method based on ADDIE Model compared the conventional method. The results show that the achievement of the experimental group is higher than that of the control group. The mean of the achievement of the experimental group was 20.51, whereas the mean of the achievement of the control group was 15.06. This difference can be attributed to the use of new method, i.e., the computerized method based on ADDIE Model. The researcher thinks that this is mainly due to the ability of the computerized program based on ADDIE Model to utilize sounds to aid in understanding the text.

Moreover, the instructional material was presented in an easier way than that in the traditional method. In addition the computerized program based on ADDIE Model enriches lower level bottom-up processing skills and higher level, top-down processing skills. Furthermore, the computerized program based on ADDIE Model presented the material in a sequential and logical order.

Finally, using the computerized program based on ADDIE Model can support practices for students through the experiential learning, offer students more learning motivation, enhance students' achievement, encourage greater student-teacher and peer interaction, emphasize the individual needs, regards independence from a single source of information and enlarge global understanding.

\subsection{Discussion the Result of the Second Question}

The findings of the present study show that there are statistically significant differences between the two marginal mean scores of the post response of the overall students' achievement on the reading comprehension test. This is due to the difference in the teaching method: whether the computerized method based on ADDIE Model or the conventional method is being used. The results show that the achievement of the experimental group is higher than that of the control group. The meanof the achievement of the experimental group was 22.86, whereas the mean score of the achievement of the control group was 13.03. This difference can be attributed to the use of the new method, i.e., the computerized method based on ADDIE Model. The researcher believes that this is mainly due to the ability of the computerized program based on ADDIE Model to utilize pictures to aid in understanding the text.

Moreover, the instructional material was presented in an easier way than that in the traditional method. In addition, the computerized program based on ADDIE Model enriches lower level bottom-up processing skills and higher level top-down processing skills. Furthermore, the computerized program based on ADDIE Model presented the material in a sequential and logical order.

Finally, using the computerized program based on ADDIE Model can raise the interest of reading for learners, to improve the vocabulary, fluency and comprehension of the students. Using the computerized program based on ADDIE Model also can enable students to increase their interaction with texts, pay their attention to individual needs and move students gradually from easy to more difficult problems according to their abilities.

For the researcher, there were many reasons to speak in favor of using the technology in teaching. The learning process became an activity that didn't require the direct involvement of a teacher.

The results of the study contrast with Ravichandran (2000) and Bollin's (2003) findings arguing that language teachers can be more comfortable with traditional textbooks since it is what they are used to deal with, and there is the idea that the use of computers threatens traditional literacy skills since they are heavily tied to books. They claim that this situation emerged in part because there is indispensable generation gap between teachers (many of whom did not grow up with computers) and students (who did grow up with computers). It is worth mentioning that teachers who are not technologically competent tend to believe that computers are worthless. On the contrary, most teachers who are technologically competent think that computers can facilitate language learning. On the contrary, the results of the present study showed that teachers can be comfortable with computer programs more than books since they save the time and submitted effort. Furthermore, computer programs help to develop literacy skills not threaten them. Finally, the generation gap between teachers and students can be overcome by teachers' training.

In spite of these few disagreements with previously mentioned studies, the results of the present study agree with many other studies which support the advantages of using instructional module design in designing computer programs to improve language learning and teaching. Among these are studies by Prammanee (2016), Rayanto and Rusmawan (2016), Chong (2016), Yüzen and Karamete (2016), Türker (2016), Zainuddin and Sahrir (2016), 
Khadimally (2015), Al-Shawesh and Hussin (2015), Lin (2014), Tian, and Suppasetseree, (2013), Soto(2013), Syatriana, Husain, and Jabu (2013), Hamra and Syatriana (2012), Tsai (2011), Ismail (2010), AL-Abdel Halim (2009).

In the light of results of this study, the researcher suggests that the use of technology inside and outside the classroom tends to make learning more interesting. Using instructional module design is likely to promote learners' motivation by using multimedia components. This incorporates provides the learners with real world context.

\section{Conclusion}

The computerized method based on ADDIE Model may help language teachers to promote students' achievement in listening and reading comprehension by enabling their students to discover their own mistakes and save time by locating precisely the information they need and learn according to their own pace.

\section{Research Recommendations}

1) The researcher suggests enrolling teachers in advanced and professional computer courses demonstrating ways of using technology to facilitate listening and reading comprehension. The computerized method based on ADDIE Model may address the barriers of time constrains, ways of teaching and learning language in general and listening and reading comprehension in particular.

2) The researcher recommends that more concentration and time should be devoted to listening and reading comprehension in basic schools. It is noted that students at this level lack the listening and the reading comprehension proficiency. To overcome this problem, the researcher recommends that the period that was given to each listening and the reading comprehension class should be lengthened.

3) The Ministry of Education in Jordan may benefit from the instructional program of the present study as well as similar ones when computerizing the English curricula.

The researcher believes that research in this area should continue to identify the needs of both language learning students and teachers and the role that effective technology education and integration can play to meet learners' needs.

\section{References}

AL-Abdel Halim, A. (2009). Designing a Computer-Assisted Language Learning Program (CALL) and Measuring its Effect on Jordanian Secondary School Students' Reading Comprehension in English. (Unpublished Doctoral Dissertation), Yarmouk University, Jordan.

Aldoobie, N. (2015). ADDIE Model. American International Journal of Contemporary Research, 5(6), 68-72.

Al Jamal, A. A. (2009). Listening Comprehension Processes, Strategies and Difficulties in Interactive Settings: A Case Study of Jordanian EFL Students. (Unpublished Doctoral dissertation), Yarmouk University. Jordan.

Al-Karian, K. A. (2011). The Effect of a Strategy-base Instructional Pogramme in Jordanian EFL University Students' Listening Comprehension (Unpublished Doctoral Dissertation), Yarmouk University. Jordan.

Al-Shawesh, M., \& Hussin, S. (2015). The Effect of the CAREY Program on the Students' Reading Attitude Towards Reading English Materials. English Language Teaching, 8(12), 98-111. https://doi.org/10.5539/elt.v8n12p98

Al-Zo'ubi, M. (2001). The Effect of the Teacher's Interactive Reading Aloud Technique in Tenth Grades' Achievement in Reading Comprehension (Unpublished Doctoral Dissertation), Yarmouk University. Jordan.

Bollin, G. (2003). The realities of middle school for Mexican children. The Clearing House, 76(4), 198. https://doi.org/10.1080/00098650309602002

Chong, I. (2016). Pedagogical Design Capacity and Underlying Knowledge Base of Curriculum Materials Use of a Hong Kong English Teacher.English Language Teaching, 9(5), 85-97. https://doi.org/10.5539/elt.v9n5p85

Hamra, A., \& Syatriana1, E. (2012). Model of Reading Teaching for University EFL Students: Need Analysis and Model Design. English Language Teaching, 5(10), 1-11. https://doi.org/10.5539/elt.v5n10p1

Ismail, I. (2010). The Effects of CBI Lesson Sequence Type and Field Dependence on Learning from Computer-based Cooperative Instruction in WEB. The Turkish Online Journal of Educational Technology(TOJET), 9(1), 221-234.

Jarrah, N, S. (2008). The Effect of Think Aloud Strategy in Jordanian Eighth Grade students' Reading 
Comprehension (Unpublished Doctoral Dissertation), Yarmouk University. Jordan.

Khadimally, S. (2015). Designing Effective Curricula With an Interactive Collaborative Curriculum Design Tool (CCDT). TOJET: The Turkish Online Journal of Educational Technology, 14(3), 32-62.

Lin, L. (2014). Teaching Design Based on English Listening and Speaking of E-learning. Bio Technology An Indian Journal, 10(14), 7629-7635.

Manichander, T. (2016). E-EDUCATION (1st ed), Lulu Press, Inc.

Marrison, S. (2002). Interactive Language Learning on the Web. Retrieved July 24, 2008, from http://www.cal.org/resources/digist/0212morrison.html

Petty, G. (2004). Teaching Today: A Practical Guide (3rd ed). Cheltenham: Nelson Thornes Ltd.

Prammanee, N. (2016). Applying ADDIE Model for Research and Development: An Analysis Phase of Communicative Language of 9 Grade Students. In the 5th Burapha University International Conference 2016: Harmonization of Knowledge towards the Betterment of Society (pp. 416-426). Thailand: Burapha University.

Ravichandran, T. (2000). Computer-assisted Language Learning (CALL) in the Perspective of the Interactive Approach Advantages and Apprehensions. CALL, 30(4), 1-15.

Rayanto, Y., \& Rusmawan, P. (2016). The Implementation of C-ID, R2D2 Model on Learning Reading Comprehension. Journal of Education and Practice, 3(7), 62-68.

Singhal, M., \& Vohra, Sh. (2011). Importance of Developing Analytical Listening Skills While Teaching English as a Second Language to a Mixed Ability Class. Learning Community, 2(1), 135-140.

Soto, V. (2013). Which Instructional Design Models are Educators Using to Design Virtual World Instruction? MERLOT Journal of Online Learning and Teaching, 3(9), 364-375.

Syatriana, E., Husain, D., \& Jabu, B. (2013). A Model of Creating Instructional Materials Based on the School Curriculum for Indonesian Secondary Schools. Journal of Education and Practice, 4(20), 10-19.

Tian, X., \& Suppasetseree, S. (2013). Development of an Instructional Model for Online Task-Based Interactive Listening for EFL Learners. English Language Teaching, 6(3), 31-41. https://doi.org/10.5539/elt.v6n3p30

Tsai, Sh. (2011). Multimedia Courseware Development for World Heritage Sites and its Trial Integration into Instruction in Higher Technical Education. Australasian Journal of Educational Technology, 7(27), 1171-1189. https://doi.org/10.14742/ajet.911

Türker, F. (2016). Design Process for Online Websites Created for Teaching Turkish as a Foreign Language in Web Based Environments. Academic Journal, 11(8), 642-655.

Yüzen, A., \& Karamete, A. (2016). Computer Assisted Educational Material Preparation for Fourth Grade Primary School Students' English Language Class in Teaching Numbers. European Journal of Contemporary Education, 15(1), 94-104.

Zainuddin, N., \& Sahrir, M. (2016). Multimedia Courseware for Teaching Arabic Vocabulary: Let's Learn from the Experts. Universal Journal of Educational Research, 4(5), 1167-1172. https://doi.org/10.13189/ujer.2016.040529

\section{Copyrights}

Copyright for this article is retained by the author(s), with first publication rights granted to the journal.

This is an open-access article distributed under the terms and conditions of the Creative Commons Attribution license (http://creativecommons.org/licenses/by/4.0/). 